\title{
COMPARATIVE CHARACTERISTICS OF NOCARDIA VACCINII IMV B-7405 SURFACE ACTIVE SUBSTANCES AND PHYTOLAVIN PREPARATION AS AGENTS FROM BACTHERIOSIS
}

\author{
Kh. Berehova, I. Sydor, L. Nykytiuk, T. Pirog
} National University of Food Technologies

\begin{tabular}{l}
\multicolumn{1}{c}{ Key words: } \\
Nocardia vaccinii IMB \\
B-7405 \\
Phytolavin \\
Surface-active substances \\
Phytopathogenic bacteria \\
Antimicrobial action \\
Technical glycerol \\
\hline \multicolumn{1}{c}{ Article history: } \\
Received 13.03.2018 \\
Received in revised form \\
28.03.2018 \\
Accepted 20.04.2018 \\
\hline
\end{tabular}

Corresponding author:

Kh. Berehova

E-mail:

npnuht@ukr.net

\begin{abstract}
In the article antimicrobial action of Nocardia vaccinii IMB B-7405 surfactants on phytopathogenic bacteria Pseudomonas, Pectobacterium and Xanthomonas genera was studied and also cost of cultivation media for the culture liquid obtaining by Streptomyces griseus 420 (producer of streptotricin antibiotics - components of Phytolavin preparation) and N.vaccinii IMB B-7405, required for the treatment of rape crops to control number of phytopathogens was compared.

It was established that the minimum inhibitory concentrations of N.vaccinii IMB B-7405 surfactants on studied phytopathogenic bacteria Pseudomonas, Pectobacterium i Xanthomonas were $19-80 \mu \mathrm{g} / \mathrm{ml}$, which are comparable to those of the known microbial surfactants.

Theoretical calculations have shown that costs of cultivation medium for obtaining N.vaccinii IMB B-7405 culture liquid, necessary for double processing of rape crops with an area 865.2 thousand hectares, is $5438 \mathrm{UAH}$, while for obtaining Phytolavin preparation — 9816 UAH. Using cheap industrial waste for biosynthesis N.vaccinii IMB B-7405 surfactants (a mixture of technical glycerol — waste from biodiesel and molasses - from sugar production) and possibility of their using as a culture liquid significantly reduces the cost of these preparations.

The ability of N.vaccinii IMB B-7405 surfactants to exhibit high antimicrobial activity (MIC $19-80 \mu \mathrm{g} / \mathrm{ml}$ ) in relation to phytopathogenic bacteria makes it possible to consider them as promising preparations for use in crop production.
\end{abstract}

DOI: $10.24263 / 2225-2924-2018-24-2-5$

ПОРІВНЯЛЬНА ХАРАКТЕРИСТИКА ПОВЕРХНЕВОAКТИВНИХ РЕЧОВИН NOCARDIA VACCINII IMB B-7405 I ПРЕПАРАТУ ФІТОЛАВІН ЯК ЗАСОБІВ ВІД БАКТЕРІОЗІВ

\author{
Х.А. Берегова, І.В. Сидор, Л.В. Никитюк, Т.П. Пирог \\ Національний університет харчових технологій
}

У статті досліджено антимікробну активність поверхнево-активних речовин (ПАР) Nocardia vaccinii IMB B-7405 щзодо фітопатогенних бактерій 
родів Pseudomonas, Pectobacterium i Xanthomonas i порівняно вартість поживних середовищ для отримання культуральної рідини Streptomyces griseus 420 (продуцеента стрептотрицинових антибіотиків - складових відомого препарату Фітолавін) та $N$. vaccinii IMB B-7405, необхідної для обробки посівів ріпаку з метою контролю чисельності фітопатогенів.

Встановлено, що мінімальні інгібуючі концентрації ПАР N. vaccinii IMB B7405 щъодо досліджуваних фiтопатогенних бактерій Pseudomonas, Pectobacterium i Xanthomonas становили 19-80 мкг/мл, щьо є порівнянним із встановленими для відомих у світі мікробних ПАР.

Теоретичні розрахунки показали, щзо витрати на приготування поживного середовища для отримання постферментаиійної культуральної рідини N.vaccinii IMB B-7405, необхідної для двократної обробки посівів ріпаку площею 865,2 тис. га, становлять 5438 грн, у той час як для одержання препарату Фітолавін - 9816 грн. Використання дешевих промислових відходів для одержання ПАР N. vaccinii IMB B-7405 (суміші технічного глічерину відходу виробництва біодизелю та меляси - від иукрового виробництва) $i$ можливість застосування їх у вигляді культуральної рідини суттєво знижує собівартість таких препаратів.

Здатність ПАР N.vaccinii IMB B-7405 проявляти високу антимікробну активність (МІК 19—80 мкг/мл) щуодо фітопатогенних бактерій дає змогу розглядати їх як перспективні препарати для застосування у рослинництві.

Ключові слова: Nocardia vaccinii IMB B-7405, Фітолавін, поверхневоактивні речовини, фітопатогенні бактерії, антимікробна дія, технічний глічерин.

Постановка проблеми. Гострою проблемою аграріїв України в останні роки стало поширення маловідомих бактеріозів, які донедавна знищували 2$5 \%$ урожаю. Відсоток уражених цими хворобами рослин значно зростає 3 кожним роком і може сягати до 50\% втрат врожаю [1].

До основних стратегічних сільськогосподарських культур України належить ріпак, насіння якого містить $30-50 \%$ олії виняткової калорійності та енерговіддачі, що в поєднанні з урожайністю (1 га посівів дає приблизно 1,1 т олії, що втричі більше, ніж соя, та вдвічі, ніж соняшник) вивело ріпак у лідери як сировину для одержання біодизелю. Передбачається, що частка біопалива у загальному виробництві рідкого палива у країнах ЄС до 2020 р. становитиме 20\% [2]. Важливість ріпаку як енергетичної культури позначилася на площах, відведених під нього у світі. Так, у 1990 р. вони становили 18 235, а у 1994 збільшилися до 22453 тис. га. Станом на 2014 р. тільки в Україні площі озимого ріпаку займали 865,2 тис. га. У травні-червні 2017 р. ціна на ріпак становила 5300 грн/т [1].

Відомо, що бактеріоз коренів озимого ріпаку (збудники - бактерії родів Xanthomonas або Pseudomonas) є причиною зниження врожаю на 40-50\%. Масштабне одержання біодизелю з ріпакової олії в Україні можливе за умови залучення інвестицій у будівництво переробних потужностей, необхідних для утилізації гліцеринової фракції - відходів виробництва цього виду біопали- 
ва, а також формування гарантованого сировинного забезпечення, що передбачає досягнення стабільності врожаю та збільшення площі посіву ріпаку.

Однією з причин несвоєчасного виявлення бактеріозів $є$ схожість симптоматики цих хвороб з нестачею поживних елементів [3]. Для боротьби з бактеріозами сільськогосподарських культур використовують агротехнічні, фізико-механічні і хімічні методи. Останні, хоча й ефективні, проте негативно впливають на довкілля і спричиняють виникнення резистентних форм бактерій. Розповсюдженню бактеріальних хвороб сільськогосподарських культур певною мірою сприяє застосування фунгіцидів і пестицидів (протруйників, інсектофунгіцидів, гербіцидів), які не діють на фітопатогенні бактерії та $\epsilon$ екологічно небезпечними.

Враховуючи щорічні втрати врожаю в Україні через бактеріози, а також необхідність використання недорогих та екологічно безпечних препаратів, які будуть ефективними щодо фітопатогенних бактерій, актуальною є розробка нових методів біологічного контролю бактеріозів сільськогосподарських культур.

Особливу увагу науковців як антимікробні агенти привертають поверхнево-активні речовини (ПАР) мікробного походження завдяки нетоксичності, стабільності у широкому діапазоні $\mathrm{pH}$ та температур порівняно із синтетичними аналогами [4]. Виробництво мікробних ПАР у світі стримується високою вартістю біосинтезу, виділення та очищення цільового продукту [5]. Тому актуальними є дослідження, спрямовані на здешевлення процесу одержання мікробних ПАР.

Раніше на кафедрі біотехнології і мікробіології Національного університету харчових технологій із забруднених нафтою зразків грунту було виділено нафтоокислювальні бактерії, ідентифіковані як Nocardia vaccinii K-8. Штам К-8 було депоновано у Депозитарії мікроорганізмів Інституту мікробіології і вірусології ім. Д.К. Заболотного Національної академії наук України за номером IMB В-7405. Встановлено здатність N.vaccinii IMB B-7405 до синтезу ПАР на різних субстратах, в тому числі й промислових відходах, розроблено шляхи інтенсифікації синтезу ПАР та досліджено деякі їхні біологічні властивості [6;7].

Мета статті дослідити антимікробну дію ПАР N.vaccinii IMB B-7405 на фітопатогенні бактерії родів Pseudomonas, Pectobacterium i Xanthomonas i порівняти вартість поживних середовищ для отримання культуральної рідини Streptomyces griseus 420 (продуцент стрептотрицинових антибіотиків складових відомого препарату Фітолавін) та $N$. vaccinii IMB B-7405, необхідної для обробки посівів ріпаку з метою контролю чисельності фітопатогенів.

Матеріали і методи. N.vaccinii IMB В-7405 вирощували в рідкому мінеральному середовищі такого складу (г/л): $\mathrm{NaNO}_{3}-0,5 ; \mathrm{MgSO}_{4} \times 7 \mathrm{H}_{2} \mathrm{O}-0,1$; $\mathrm{CaCl} \times 2 \mathrm{H}_{2} \mathrm{O}-0,1 ; \mathrm{KH}_{2} \mathrm{PO}_{4}-0,1 ; \mathrm{FeSO}_{4} \times 7 \mathrm{H}_{2} \mathrm{O}-0,001$, дріжджовий автолізат $-0,5 \%$ (об'ємна частка). Як джерело вуглецю використовували суміш промислових відходів ( $8 \%$ технічного гліцерину та $1 \%$ меляси). Як посівний матеріал використовували культуру в експоненційній фазі, вирощену на суміші $0,25 \%$ технічного гліцерину і $0,25 \%$ меляси. Кількість інокуляту $\left(10^{4}-\right.$ $10^{5}$ кл/мл) становила $10 \%$ від об'єму середовища. Культивування N.vacinnii 
IMB B-7405 здійснювали в колбах об'ємом 750 мл із 100 мл середовища на качалці $\left(320\right.$ об/хв) при $30^{\circ} \mathrm{C}$ упродовж 120 год. У дослідженнях використовували поверхнево-активні речовини у вигляді розчину ПАР, екстрагованих з супернатанту сумішшю Фолча (хлороформ і метанол, 2:1) як описано у наших попередніх працях [6;7].

У дослідженні використовували фітопатогенні бактерії з Української колекції мікроорганізмів: Pectobacterium carotovorum УКМ В-1095, Pseudomonas syringae pv. atrofaciens УKM В-1015, Pseudomonas syringae pv. coronafaciens -УКМ В-1154, Xanthomonas campestris pv. campestris УКМ В-1049. Об'єктами дослідження були також фітопатогенні бактерії з колекції відділу фітопатогенних бактерій Інституту мікробіології і вірусології ім. Д.К. Заболотного НАНУ Pseudomonas corrugata 9070, Xanthomonas vesicatoria 7790. Штами фітопатогенних бактерій були люб'язно надані співробітниками відділу фітопатогенних бактерій Інституту мікробіології і вірусології ім. Д.К. Заболотного НАНУ.

Визначення мінімальної інгібуючої концентрації (МІК) здійснювали методом двократних серійних розведень у м'ясо-пептонному бульйоні (МПБ) як описано у [8]. У стерильних умовах у 10 пробірок вносили по 1 мл середовища, у першу додавали 1 мл розчину ПАР (препарат 2) певної концентрації, після чого перемішували, відбирали 1 мл і переносили у наступну пробірку. Аналогічно проводили розведення для інших дев'яти пробірок. 3 останньої пробірки відбирали 1 мл. Кінцевий об'єм у кожній пробірці становив 1 мл (МПБ і розчин ПАР), а концентрація ПАР у кожній наступній пробірці знижувалася у 2 рази. Як контроль використовували 1 мл МПБ без додавання розчину ПАР. Далі у кожну з пробірок вносили по 0,1 мл суспензії тест-культур $\left(10^{5}-10^{6} \mathrm{KУO} / \mathrm{cm}^{3}\right)$ та перемішували. Пробірки інкубували впродовж 24 год при $28-30^{\circ} \mathrm{C}$.

Результати оцінювали візуально за помутнінням середовища: $(+)-$ пробірки, в яких спостерігали помутніння (ріст тест-культури), (-) - помутніння не було (ріст відсутній). Мінімальну інгібуючу концентрацію розчину ПАР визначали як концентрацію ПАР в першій пробірці, де ріст був відсутній.

3 метою оцінки ефективності застосування ПАР N.vaccinii IMB B-7405 для контролю чисельності збудників хвороб ріпаку здійснювали порівняння витрат на приготування поживних середовищ для отримання культуральної рідини штаму IMB B-7405 i Streptomyces griseus 420 (продуцент стрептотрицинових антибіотиків - складових відомого препарату Фітолавін), необхідної для обробки певної площі посівів ріпаку.

Усі досліди проводили в трьох повторах, кількість паралельних визначень в експериментах становило від 3 до 5. Статистичну обробку експериментальних даних проводили, як описано раніше [6; 7]. Відмінності середніх показників вважали достовірними при рівні значущості $p<0,05$.

Результати і обговорення. У табл. 1 наведено мінімальні інгібуючі концентрації ПАР N.vaccinii IMB B-7405 щодо фітопатогенних бактерій родів Pseudomonas, Pectobacterium i Xanthomonas. Які засвідчують дані табл. 1, цим поверхнево-активним речовинам притаманна висока антимікробна активність щодо збудників бактеріозів сільськогосподарських культур [7], завдяки чому 
вони є перспективними для застосування у рослинництві з метою контролю чисельності фітопатогенних бактерій. Так, МІК ПАР N.vaccinii IMB B-7405 щодо представників родів Pseudomonas, Pectobacterium i Xanthomonas становить 19-80 мкг/мл (табл. 1).

Зазначимо, що у літературі є лише окремі праці, в яких автори визначали МІК мікробних ПАР щодо фітопатогенних бактерій. Мінімальна інгібуюча концентрація сурфактину, синтезованого B. subtilis 6051, щодо бактерій P. syringae pv. tomato DC3000 становила 25 мкг/мл. Значення МIК рамноліпідів щодо Fusarium solani, Penicillium funiculosum, Alternaria становила 16-75 мкг/мл, МІК софороліпідів щодо Glomerella cingulata — 50 мкг/мл (цит. за [7]). Рамноліпідам P. aeruginosa AT110, були притаманні фунгіцидні властивості щодо Aspergillus niger та Gliocadium virens (16 мг/мл); Chaetonium globosum, Penicillium crysogenum i Aureobasidium pullulans (32 мг/мл), Botrytis cinerea i Fusarium solani (18 мг/мл) (цит. за [7]).

Таблиия 1. Антимікробна активність ПАР N.vacinnii IMB B-7405 щодо фітопатогенних бактерій

\begin{tabular}{|c|c|c|}
\hline Фітопатогенні бактерії & Хвороби сільськогосподарських рослин & $\begin{array}{l}\text { МІК, } \\
\text { мкг/мЛ }\end{array}$ \\
\hline $\begin{array}{l}\text { P. syringae } \mathrm{pv} . \\
\text { coronafaciens } \\
\text { УКМ В-1154 }\end{array}$ & $\begin{array}{l}\text { Збудник ореольного (бурого) бактеріозу } \\
\text { сільськогосподарських культур }\end{array}$ & 21 \\
\hline $\begin{array}{c}\text { P. syringae pv. } \\
\text { atrofaciens УКМ B-1015 }\end{array}$ & Збудник базального бактеріозу зернових & 80 \\
\hline P. corrugata 9070 & $\begin{array}{c}\text { Викликає некроз серцевини стеблин ріпаку, томатів, } \\
\text { перцю }\end{array}$ & 38 \\
\hline $\begin{array}{l}\text { P. carotovorum } \\
\text { УКМ B-1095 }\end{array}$ & $\begin{array}{c}\text { Поліфаг, збудник м’якої гнилі соняшнику, слизового } \\
\text { бактеріозу капусти та стеблової гнилі кукурудзи та } \\
\text { ріпаку }\end{array}$ & 75 \\
\hline X. vesicatoria 7790 & $\begin{array}{c}\text { Збудник чорної бактеріальної плямистості капусти, } \\
\text { томатів і деяких сільськогосподарських технічних } \\
\text { культур (ріпак, соняшник, соя, жито) }\end{array}$ & 21 \\
\hline $\begin{array}{l}\text { X. campestris pv. } \\
\text { campestris } \\
\text { УКМ В-1049 }\end{array}$ & $\begin{array}{c}\text { Збудник чорної гнилі капусти, бактеріального некрозу } \\
\text { соняшнику та бактеріального опіку ріпаку }\end{array}$ & 19 \\
\hline
\end{tabular}

На теперішній час у сільському господарстві основна увага приділяється біологічним методам захисту рослин. Упродовж останніх 20 років в Україні використовують різноманітні за біологічною дією препарати з комерційними назвами Планриз БТ, Псевдобактерин-2, Спорофіт (ФітоДоктор), Бактофіт, Бізар, Поліміксобактерин, Фітоцид.

Проте засобів для боротьби саме з бактеріозами сільськогосподарських рослин $\epsilon$ не так багато: одним із таких препаратів $\epsilon$ Фітолавін, який діє на збудників бактеріозу Erwinia carotovora, P. syringae pv. syringae, Clavibacter michiganensis, Ralstonia solanacearum, Agrobacterium tumefaciens, X. campestris, P. syringae pv. Atrofaciens [9]. Препарат розроблений на основі культуральної рідини S.griseus 420, який є продуцентом стрептотрицинових анти- 
біотиків. Для отримання препарату штам 420 культивують на вуглеводвмісному поживному середовищі з подальшим вакуум-упарюванням культуральної рідини до $10 \%$ сухих речовин і висушуванням на розпилювальній сушарці.

Станом на листопад 2014 р. в Україні вироблено 2,2 млн т насіння ріпаку, площі посівів становили 865,2 тис. га (дані Державної служби статистики [10].

Згідно з Інструкцією використання біопрепарату Фітолавін пропонується двократна обробка (передпосівна обробка насіння та обприскування від початку фази кущення до фази виходу у трубку) 3 нормою витрат 2 л/т/або га насіння та рослин відповідно.

Отже, для обробки 1 га полів, засіяних ріпаком, необхідно 2 л препарату Фітолавін, 3 якого готують $0,2 \%$ робочий розчин, розбавляючи 2 л Фітолавіну у 1000 л води [11]. Для обробки 865,2 тис. га необхідно $865200 \cdot 2=1730400$ л робочого розчину Фітолавіну. Для приготування такої кількості робочого розчину потрібно $1730400 / 1000=1730,4$ л препарату Фітолавін.

Далі розраховуємо кількість г діючої речовини (антибіотиків) в 1730,4 л препарату Фітолавін, необхідної для обробки 865,2 тис. га ріпаку. У препараті Фітолавін міститься 32 г/л стрептотрицинових антибіотиків. Отже, для обробки посівів ріпаку необхідно $1730,4 \cdot 32 / 1=55372,8$ г антибіотиків.

Концентрація антибіотиків стрептотрицинів у культуральній рідині $S$. griseus 420 становить 10 г/л [12]. Отже, для обробки 865200 га посівів ріпаку потрібно 55 372,8 / $10=5537,28$ л культуральної рідини. Враховуючи, що обробку ріпаку проводять двічі, то необхідна кількість культуральної рідини становитиме $5537,28 \cdot 2=11074,6$ л. Отже, для двократної обробки 865200 га посівів ріпаку необхідно одержати 11100 л культуральної рідини S. griseus 420 .

Далі розрахуємо необхідну кількість культуральної рідини N.vaccinii IMB В-7405 для обробки такої самої площі посівів ріпаку. Як засвідчують дані, наведені у табл. 1, для контролю чисельності фітопатогенів ефективною $\epsilon$ концентрація ПАР $19-80$ мкг/мл $(0,019-0,08$ г/л). Для розрахунків беремо середнє значення ефективної концентрації ПАР, що становить 0,05 г/л.

Для обробки 1 га полів, засіяних ріпаком, необхідно 2 л розбавленої культуральної рідини (аналогічно препарату Фітолавін) з концентрацією ПАР 0,05 г/л, або 0,1 г ПАР. Для обробки 865200 га потрібно $865200 \cdot 0,1=$ $=86520$ г ПАР. Концентрація ПАР, синтезованих за умов росту N.vacinnii IMB B-7405 на суміші технічного гліцерину і меляси, становить 13 г/л ПАР. Отже, для одержання 86520 г ПАР необхідно 86 520/13 = 6 655,4 л культуральної рідини. Для двократної обробки посівів ріпаку потрібно $6655,4 \cdot 2=$ $=13$ 310,8 л, або 13400 л культуральної рідини N.vacinnii IMB B-740.

Розрахуємо вартість 1 л поживного середовища для культивування штаму S. griseus 420 і N.vaccinii IMB B-7405 (табл. 2). Отже, вартість 1 л поживного середовища для культивування N.vaccinii IMB B-7405 у 2,2 раза нижча, ніж середовища для вирощування S. griseus 420. Витрати на одержання 11100 л поживного середовища для вирощування S. griseus 420 становлять $11100 \times$ $\times 0,8843=9816$ грн, а на приготування 13400 л середовища для вирощування N. vaccinii IMB B-7405 - $134000 \cdot 4058=5438$ грн. 
Таблиця 2. Склад і вартість поживного середовища для культивування S.griseus 420 i N.vaccinii IMB B-7405

\begin{tabular}{|c|c|c|c|c|c|}
\hline Продуцент & $\begin{array}{c}\text { Компоненти } \\
\text { поживного } \\
\text { середовища }\end{array}$ & $\begin{array}{c}\text { Вміст } \\
\text { компонентів, } \\
\text { кг/л }\end{array}$ & $\begin{array}{l}\text { Ціна, } \\
\text { грн/кг }\end{array}$ & $\begin{array}{c}\text { Вартість } \\
\text { компонентів, } \\
\text { грн }\end{array}$ & $\begin{array}{c}\text { Загальна } \\
\text { вартість } 1 \text { л } \\
\text { поживного } \\
\text { середовища, } \\
\text { грн }\end{array}$ \\
\hline \multirow{8}{*}{ S. griseus 420} & Кукурудзяна мука & 0,04 & 10,42 & 0,4168 & \multirow{8}{*}{0,8843} \\
\hline & Меляса & 0,018 & 3,2 & 0,0576 & \\
\hline & Лізин & 0,0005 & 240 & 0,12 & \\
\hline & $\mathrm{KH}_{2} \mathrm{PO}_{4}$ & 0,0003 & 72 & 0,0216 & \\
\hline & $\mathrm{NaCl}$ & 0,002 & 10,4 & 0,0208 & \\
\hline & $\mathrm{MgSO}_{4} \times 7 \mathrm{H}_{2} \mathrm{O}$ & 0,0005 & 25 & 0,0125 & \\
\hline & $\mathrm{CaCO}_{3}$ & 0,005 & 30 & 0,15 & \\
\hline & Пропінол & 0,001 & 85 & 0,085 & \\
\hline \multirow{8}{*}{$\begin{array}{c}\text { N.vaccinii } \\
\text { IMB B-7405 }\end{array}$} & $\begin{array}{l}\text { Технічний } \\
\text { гліцерин }\end{array}$ & 0,1008 & 2 & 0,2016 & \multirow{8}{*}{0,4058} \\
\hline & Меляса & 0,028 & 3,2 & 0,0896 & \\
\hline & $\mathrm{NaNO}_{3}$ & 0,001 & 35 & 0,035 & \\
\hline & $\mathrm{MgSO}_{4} \times 7 \mathrm{H}_{2} \mathrm{O}$ & 0,0001 & 25 & 0,0025 & \\
\hline & $\mathrm{CaCl}_{2} \times 2 \mathrm{H}_{2} \mathrm{O}$ & 0,0001 & 55 & 0,0055 & \\
\hline & $\mathrm{KH}_{2} \mathrm{PO}_{4}$ & 0,0001 & 72 & 0,0072 & \\
\hline & $\mathrm{FeSO}_{4} \times 7 \mathrm{H}_{2} \mathrm{O}$ & 0,00001 & 40 & 0,0004 & \\
\hline & $\begin{array}{l}\text { Дріжджовий } \\
\text { екстракт }\end{array}$ & 0,00025 & 256 & 0,064 & \\
\hline
\end{tabular}

Примітка: Ціна компонентів поживних середовищ вказана станом на 2016 рік.

Отже, теоретичні розрахунки витрат на приготування поживних середовищ для отримання культуральної рідини штаму S. griseus 420 і N.vaccinii IMB B-7405, необхідної для обробки посівів ріпаку 3 метою контролю чисельності фітопатогенних бактерій, засвідчили вищу ефективність препаратів ПАР штаму IMB В-7405.

\section{Висновок}

Неконтрольоване використання антибіотиків, у тому числі й препарату Фітолавін, у сільському господарстві призводить до виникнення резистентних форм мікроорганізмів. Механізм антимікробної активності поверхневоактивних речовин, на відміну від антибіотиків, унеможливлює виникнення стійких до них бактерій. Висока антимікробна активність ПАР N.vaccinii IMB B-7405 (МІК 19-80 мкг/мл) щодо фітопатогенних бактерій дає змогу розглядати їх як перспективні для застосування у рослинництві.

\section{Література}

1. Чехов С.А. Ринок ріпаку в Україні. Продуктивність агропромислового виробництва. Економічні науки. — 2015. - № 27. - С. 77-83 [Електронний ресурс]. — Режим доступу : http://nbuv.gov.ua/UJRN/Pav_2015_27_13.

2. Rivas Casado M., Mead A., Burgess P.J., Howard D.C., Butler S.J. Predicting the impacts of bioenergy production on farmland birds. Sci Total Environ. 2014, P. 7-19. doi: 10.1016/j.scitotenv.2013.12.080. 
3. Гвоздяк P.I. Фітопатогенні бактерії. Бактеріальні хвороби рослин : Монографія / Р.І. Гвоздяк, Л.А. Пасічник, Л.М. Яковлева та ін. — Київ : ТОВ «НВП Інтерсервіс», 2011. $444 \mathrm{c}$.

4. Díaz De Rienzo M. A., Banat I. M., Dolman B. Sophorolipid biosurfactants: possible uses as antibacterial and antibiofilm agent. N.biotechnol. 2015, 32 (6), P. 720-726.

5. Rivas Casado M., Mead A., Burgess P.J., Howard D.C., Butler S.J. Predicting the impacts of bioenergy production on farmland birds. Sci. Total. Environ. 2014, P. 7-19. doi: 10.1016/j.scitotenv.2013.12.080. Epub 2014 Jan 21. PubMed PMID: 24463022.

6. Pirog T.P., Konon A.D., Beregovaya K. A., Shulyakova M.A. Antiadhesive properties of the surfactants of Acinetobacter calcoaceticus IMB B-7241, Rhodococcus erythropolis IMB Ac5017, and Nocardia vaccinii IMB B-7405. Microbiology. 2014, 83 (6), P. 732—739.

7. Pirog T.P., Konon A.D., Sofilkanich A.P., Iutinskaia G.A. Effect of surface-active substances of Acinetobacter calcoaceticus IMV B-7241, Rhodococcus erythropolis IMV Ac5017, and Nocardia vaccinii K-8 on phytopathogenic bacteria. Appl. Biochem. Microbiol. 2013, 49(4), 360 - 367. doi:10.1134/S000368381304011X.

8. Mazzola P. G., Jozala A. F., de L. Novaes L.C. Minimal inhibitory concentration (mic) determination of disinfectant and/or sterilizing agents. Brazilian J. Pharm. Sci. 2009, 45 (2), P. 241-248.

9. Пат. 2144292 Российская Федерация, МПК 7 А 01 N 63/04. Способ получения препарата для борьбы с болезнями растений / Мосин В.А., Дриняев В.А., Кругляк Е.Б., Котова Г.Л., Суставова С.И., Сафонов В.С. Опубл. 20.01.2000.

10. Публікація документів державної служби статистики України [Електронний pecypc]. - Режим доступу : www.ukrstat.gov.ua (дата звернення 12.01.2016). — Назва 3 екрана.

11. Пат. 2409951 Российская Федерация, МПК 7 А 01 N 63/04. - Средство для защиты растений / Борисова И.П., Будынков Н.И., Кругляк Е.Б., Тибаева В.Н., Тихомирова О.И. Опубл. 20.01.2000.

12. Пат. 2144292 Российская Федерация, МПК 7 А 01 N 63/04. Способ получения препарата для борьбы с болезнями растений / Мосин В.А., Дриняев В.А., Кругляк Е.Б., Котова Г.Л., Суставова С.И., Сафонов В.С. Опубл. 20.01.2000. 